\title{
Job Satisfaction and Employee's Self-Schema at Workplace: A Literature Review
}

\author{
Aida Mehrad \\ Faculty of Psychology \\ UniversitatAutònoma de Barcelona \\ aida_238@yahoo.com
}

\begin{abstract}
The purpose of the present study is to determine the relationship between job satisfaction and self-schema amongst employees at the workplace. The results of the study revealed that selfschema derived from feelings and attitudes of employees based on their satisfaction at the workplace; and, explained that employees' schemas are various, completely. This study likewise considered on job satisfaction as a main organizational factor that increases the amount of performance and presence of employees at the workplace. Also, it focused on selfschema that pivotal role in employees believes about themselves. Moreover, lack of attention to job satisfaction that influenced on employees' scheme appeared some abnormal organizational behaviors at workplace. Thus, the present study supports job satisfaction to achieve appropriate scheme among employees at the workplace.
\end{abstract}

Keywords: Job satisfaction, Self-Schema, Employee, Workplace

\section{INTRODUCTION}

All human resources need to have a suitable workplace for performing their tasks. One of the main factors that provide this situation job satisfaction (Huselid, 1995; Ahsan, Abdullah, Gun Fie, \& Alam, 2009). This organizational factor refers to how much individuals feel positive about their job and work environment. In fact, the job satisfaction is a result of employees' perception of how well their job provides those things that are noticed as vital (Aziri, 2011). In her major study, Luthans (1998) explained that there are three significant dimensions of job satisfaction. These dimensions included: 1) job satisfaction assumed as an emotional response to a job condition, 2) job satisfaction is often determined by how well consequence meet or 
exceed expectations, and 3) job satisfaction represents numerous related attitudes which are most imperative characteristics of a job about which people have an operative response. In other words, job satisfaction depends on various factors such as the economically, social, and cultural conditions in a given country, education, gender, long of working, aspects, etc. In truth, job satisfaction cannot be a talk of where there is an absence of motivation (Tella, Ayeni, \& Popoola, 2007).

On the other hand, job dissatisfaction assumed as a predictor of some abnormal organization behaviors such as abandoning a job from an employee (Noordin \& Jusoff, 2009). In this regard, the society faced various problems that considered as a serious threat to employees and also the workplace. Overall, the job dissatisfaction as an important indicator that decreases the level of employee performance; and also, it leads to absenteeism, turnover intentions, burnout, and disengagement amongst employees. Additionally, this uncommon organizational factor changes employees' attitude and perception at the workplace (Maslach \& Leiter, 1997; Wan Ahmad \& Abdurahman, 2015). On the whole, the job satisfaction and dissatisfaction related to employees believe and attitudes toward their job (Tella et al., 2007).

One of the main factors that associated with job satisfaction amongst employees is self-schema. This factor refers to individuals' views and thoughts. These thoughts are used to guide and organize information processing, especially when the information is significant to the self (Kassin, Fein, \& Markus, 2008).Indeed, self-schema explained believes and considers of individuals about themselves; as well as, this factor likewise refers to how individuals knew themselves and explained their physical characteristics and also personality trait in the society.In reality, this factor shows the understanding of individuals toward other people and also their environment; based on this perception they release various behavior and reactions(Wilderdom, 2003). 
In Schema Theory explained that individuals based on their situation and lifestyle behave; likewise, each of them has special behavior and performance in society. Regarding this theory, researchers explained that any interest and requirement amongst individuals provide an appropriate condition for developing their skill and performance. Because individuals based on their needs try to obtain necessary information and improve themselves (Rumelhart,1980).

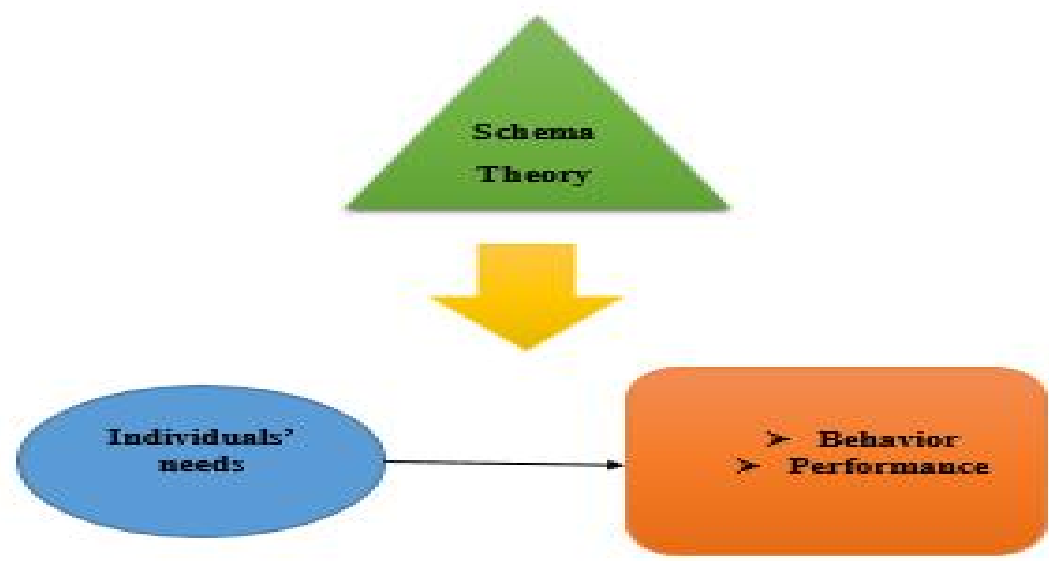

Figure 1. Schema Theory

The schema for each form based on his or her characteristics and activity. This factor states to a particular schema determined for a specific dimension. In fact, schema forms based on each activity; as well, it depends on individual feeling.For case in point, an individual who works in an organization as an employee would have an employee schema that impacted by various factors at the workplace (Valentino, Cicchetti, Rogosch, \&Sheree,2008). In continue, the study will be clarified the association between self-schema and job satisfaction amongst employees at workplaces. 


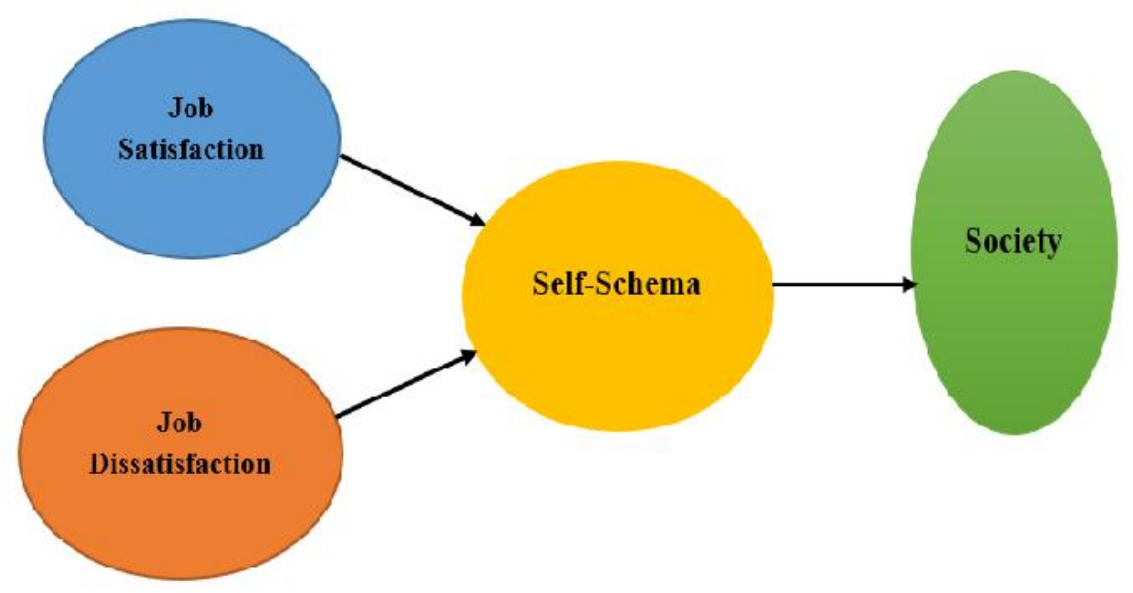

Figure 2. Conceptual Framework of the Study

\section{Relation between Job Satisfaction and Self-Schema}

Job satisfaction has the main role on employees feeling and performance; furthermore, should be focused on this organizational factor and conduct it in the correct way (Mohammad, Quoquab Habib, \& Alias, 2011). In general, there are two main reasons that explained why should be concerned about job satisfaction. The first one is workplaces (managers, supervisors, etc.) that have a moral responsibility to do what they can to provide their employees with a satisfying work environment. Also, the second one is, they believe that the behavior of satisfied employees will make positive contributions to the workplace. As well, this factor effects on their attitudes, schema, and knowing themselves in the workplace and society (Noordin \& Jusoff, 2009; Maharjan, 2012). In a study conducted by Tella et al. (2007), it was revealed that attitudes and schemas could help organize and interpret information. This view is supported by Lo, Ramayah, Min, and Songan (2010) who explained that 
schemas could be useful because they allow taking shortcuts in understanding the vast amount of information that is available in employees' environment. Even though, strengthen their relation with another people and create convenient communication with them.A seminal investigation in this area is the work of Burton and Dukes (1990) who described that job satisfaction obtaining skills linked to selfconcept and self-schema about satisfaction for knowing the environment. Also, these believe, and schemas have direct to the self and recognize behavior and communications with others in the society and workplace. Similarly, job satisfaction can change individuals' attitudes about community and society. Particularly, the happier employee shows, the higher level of job satisfaction. It is assumed that positive attitude towards work and greater organizational commitment increases job satisfaction which in return enhances the performance of the individual (Ahmad \&Oranye,2010).Besides, the schema forms based on everything that individuals think and believe about it; and also, this factor developed during a time. The schema is differently amongst individuals because each person thinks based on his/her activity and has a particular schema (Bartoli, 2008; Cervone\& Pervin, 2008; Kassin et al., 2008).

However, job satisfaction assumed a key instrument for organizational health and increased quality largely depends upon the human resources that effect on individual behavior and appears in society in different forms. In general, job satisfaction refers to an individual's positive emotional reactions to a particular job (Stahl, 2004). Employees spend a major part of their life at the workplace hence the factors related to job satisfaction and employee behavior and their implication are important to measure. Job satisfaction is an attitude of an employee over a period of his/her job. Job satisfaction related to the schema and social behavior; furthermore, measuring these items at the workplace is not an easy task but in daily behavior in the workplace are noticeable and can effect to the efficiency of individuals (Yasir\&Fawad, 2009). The relationship of job satisfaction with worker behavior has 
been well documented. The negative feelings towards work may be termed job dissatisfaction while there has been a wide range of theory building to explain job satisfaction's origins and facets, it is apparent that no single theory can explain the phenomenon, completely (Altbach, Reisberg, \& Rumbly, 2009). Job satisfaction has been investigated as an uni-dimensional phenomenon, often referred to as overall or general job satisfaction. Also, job satisfaction has also been studied as a multidimensional phenomenon (DeNobile \& McCormick, 2008). The definition of job satisfaction has obviously progressed through the decades, but most versions share the belief that job satisfaction is a work-related positive affective reaction. There seems to be less consistency when talking about the causes of job satisfaction.In general, job satisfaction is influenced by many factors, including personal traits and characteristics of the job and also impacted on varying factors such as self-schema (Worrell, 2004). The self-schema is an individual's total self-concept that refers to a hypothesis into a theory and books into a library. In reality, this factor is important because it leads to interpreting and recalling individuals based on their life experience. It contains particular role in society; additionally, a generalization based on social stereotypes. The self-schema grows into self-perpetuating when the individual chooses activities based on expectations. Individual's views hold about themselves that guide the processing of self-relevant information. On matters relevant to self-schema, individuals make a rapid judgment about them and are quick to recall past actions or predict future actions. Likewise, the schema is a mental framework that allows individuals to organize large amounts of information in an efficient manner. In overall, the schemas are unique in integrating and summarizing a person's thoughts, feelings, and experiences about the self in a specific behavioral domain (Hammen\&Zupan, 1984). In the vision of all that has been stated so far, one may suppose that job satisfaction is one of the main factors that can contribute in employee's schema. 


\section{CONCLUSION}

The presence of various and inappropriate schemas amongst employees can be destructive for workplace and society. In reality, the negative beliefs and attitudes toward job and workplace lead to abnormal organizational behavior. Furthermore, the modern society and workplace should be recognizing the effective organizational factors such as job satisfaction and establish convenient situation to developing this factor. Most of the time, workplaces, and society not have enough knowledge for growing acceptable circumstances and also to apply an advanced method for employees. As a whole, it seems that workplaces should obtain progressive information for improving the appropriate condition for satisfying the employees and

present them good facilities; likewise, recover their beliefs and schemas toward themselves and the society. This study has found that the role of job satisfaction that should be supported by workplace and conduct it in the correct way.

\section{REFERENCES}

Ahmad, N.,\&Oranye, N.O. (2010) Empowerment, job satisfaction, and organizational commitment: A comparative analysis of nurses working in Malaysia and England. Journal of Nursing Management, 18 (5), 582-591.

Ahsan, N., Abdullah, Z., Gun Fie, D. Y., \& Alam, S. S (2009). A study of job stress on job satisfaction among university staff in Malaysia: Empirical study. European Journal of Social Science, 8(1), 121-131.

Altbach, G. P., Reisberg, L., \& Rumbly, E. L. (2009). Trends in Global Higher Education: Tracking an Academic Revolution. Paris: UNESCO.

Aziri, B. (2011). Job satisfaction: A literature review. Management Research and Practice, 3(4), 77-86. 
Journal of Educational, Health and Community Psychology

Vol 5, No 3, 2016.
Aida Mehrad

Bartoli, A. M. (2008). Self-schema. Retrieved March 3, 2009, from Angela M. Bartolli, Psychology Web site: http://webspace.ship.edu/ambart/PSY_220/selfschemaol.htm

Burton, J.W., \&Dukes, F. (1990a). Conflict: Readings in Management and Resolution. America, New York: St. Martin's Press.

Cervone, D., \& Pervin, L. (2008). Personality Theory and Research. Hoboken: John Wiley \& Sons, Inc.

DeNobile, J. J., \& McCormick, J. (2008). Organizational communication and job satisfaction in Australian Catholic primary schools. Educational ManagementAdministration \& Leadership, 36(1), 101-122.

Huselid, M. A. (1995). The impact of human resource management practices on turnover, productivity, and corporate financial performance. Academy of Management Journal, 38(3), 635-872.

Kassin, S., Fein, S., \& Markus, H. (2008). Social Psychology(7 $7^{\text {th }}$ ed.). Boston: Houghton Mifflin Company.

Hammen, C., \&Zupan, B. A. (1984). Self-schemas, depression, and the processing of personal information in children. Journal of Exp Child Psychol, 37(3): 598608.

Lo, M. C., Ramayah, T., Min, H. W.,\&Songan, P. (2010). The relationship between leadership styles and organizational commitment in Malaysia: Role of leadermember exchange, Asia Pacific Business Review, 16, (1-2), 79-103.

Luthans, F. (1998). Organizational Behavior( $8^{\text {th }}$ ed.). Boston: Irwin Mc-Graw Hill

Maharjan, S. (2012). Association between work motivation and job satisfaction of college teachers. Administrative and Management Review, 24(2), 45-55.

Maslach, C., \& Leiter, M. P. (1997). The Truth About Burnout How Organizations Cause Personal Stress and What to do About it $\left(1^{\text {st }}\right.$ ed.). Jossey-Bass, San Francisco, CA.

Mohammad, J., Quoquab Habib, F., \& Alias, M. A. (2011). Job satisfaction and organizational citizenship behavior: An empirical study at higher learning institutions. Asian Academy of Management Journal, 16(2), 149-165.

Noordin, F., \& Jusoff, K. (2009). Levels of job satisfaction amongst Malaysian 
Journal of Educational, Health and Community Psychology

Vol 5, No 3, 2016.

Aida Mehrad

academic staff. Asian Social Science, 5(5), 122-128.

Rumelhart, D.E. (1980). Schemata: the building blocks of cognition. In: R.J. Spiro et al. (eds). Theoretical Issues in Reading Comprehension, Hillsdale, NJ: Lawrence Erlbaum.

Stahl, M. J. (2004). Encyclopedia of Health Care Management. Sage Publications, Inc.

Tella, A., Ayeni, C. O., \& Popoola, S. O. (2007). Work motivation, job satisfaction, and organizational commitment of library personnel in academic and research libraries in Oyo state, Nigeria. Library Philosophy and Practice, 1-16.

Valentino, K., Cicchetti, D., Rogosch, F. A., Toth, S. L. (2008). True and false recall and dissociation among maltreated children: The role of self-schema.

Development and Psychopathology, 20(1), 213-32. Retrieved March 3, 2009, from Research Library database. (Document ID: 1601417001).

Wan Ahmad, W. I., \& Abdurahman, S. M. (2015). Job satisfaction among academic the staff of Universiti Utara Malaysia: A work environment perspective. Mediterranean Journal of Social Sciences, 7(3), 251-256.

Wilderdom, (2003). The Role of Schemas in Personality. Retrieved March 4, 2009, from Wilderdom a project in natural living \& transformation Web site:http://wilderdom.com/personality/L111RoleOfSchemasInPersonality.htm 1

Worrell, T. G. (2004). School Psychologists' Job Satisfaction: Ten Years Later. (Unpublished doctoral dissertation). University of Polytechnic Virginia, United States.

Yasir, K., \&Fawad, H. (2009). Pay and Job Satisfaction: A Comparative Analysis of Different Pakistani Commercial Banks. Munich Personal RePEcArchive, 16059, 1-20. 